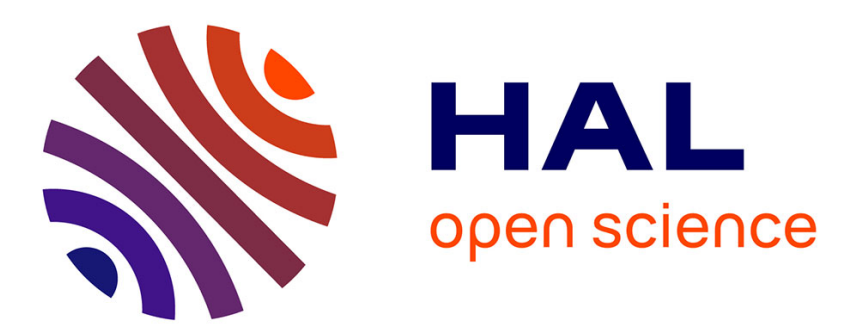

\title{
Preventing chiefs from being chiefs: An ethnography of a co-operative sheet-metal factory
}

Stéphane Jaumier

\section{To cite this version:}

Stéphane Jaumier. Preventing chiefs from being chiefs: An ethnography of a co-operative sheet-metal factory. Organization, 2016, 10.1177/1350508416664144 . hal-01366601

\section{HAL Id: hal-01366601 \\ https://hal.science/hal-01366601}

Submitted on 15 Sep 2016

HAL is a multi-disciplinary open access archive for the deposit and dissemination of scientific research documents, whether they are published or not. The documents may come from teaching and research institutions in France or abroad, or from public or private research centers.
L'archive ouverte pluridisciplinaire HAL, est destinée au dépôt et à la diffusion de documents scientifiques de niveau recherche, publiés ou non, émanant des établissements d'enseignement et de recherche français ou étrangers, des laboratoires publics ou privés. 
Stéphane Jaumier

Assistant Professor

Grenoble Ecole de Management, France

Email: stephane.jaumier@grenoble-em.com

\title{
Preventing chiefs from being chiefs: An ethnography of a co-operative sheet-metal factory
}

\begin{abstract}
Knowledge of how democracy and equality are practically achieved within member-based organisations such as co-operatives remains underdeveloped in the literature. In order to investigate this question, the present study is based on a piece of ethnographic work, namely one year of participant observation as a factory worker, which I conducted within a French co-operative sheet-metal factory. Pondering the presence within the co-operative of seemingly powerless chiefs, I draw on the works of French anthropologist Pierre Clastres (1934-1977) on stateless societies in order to study co-operators in their 'continual effort to prevent chiefs from being chiefs' (Clastres, 1987: 218). Three types of day-to-day practices appear to be central for members of the co-operative in circumventing the coalescence of power in the hands of their chiefs: a relentlessly voiced refusal of the divide between chiefs and lay members; a permanent requirement for accountability, and endless overt critique towards chiefs; and the use of schoolboy humour. The case, as analysed through a Clastrian lens, evidences a novel avenue that is conducive to avoiding the fate of oligarchisation within democratic organisations. Indeed, it shows how power can be kept at bay by being named and then embodied in a figure, who is eventually - through mostly informal practices - stripped of all authority. In addition, it suggests that our understanding of co-operation could be greatly improved if researchers' dominant focus on governance was complemented by studies anchored in the everyday experience of co-operators.
\end{abstract}

\section{Keywords}

Pierre Clastres; organisational democracy; hierarchy; worker co-operatives; ethnography 
One of the main threats looming for member-based organisations - i.e. organisations that on principle rely on the equal status and democratic participation of their members to reach their goals $^{1}$ (Birchall, 2011; Spear, 2004) - lies in the progressive emergence of a commanding elite in their midst. This phenomenon is generally referred to as the 'iron law of oligarchy' (Michels, 1915). Since Michels' seminal contention, numerous studies have confirmed how difficult it is for democratic organisations to overcome the fate of oligarchisation (Cornforth et al., 1988). In particular, a series of failed experiments among social movements of the 1960s has provided evidence that simply doing away with any kind of formal organising and hierarchy does not achieve this (Maeckelbergh, 2011). Indeed, in this context, the absence of legitimate structures of decision-making allows power to be concentrated in the hands of cliques whom it is difficult to hold accountable for their actions (Freeman, 2013[1972]). Challenges to the 'iron law' have thus progressively integrated the idea that specific conditions need to prevail in order for democratic organisations to retain their egalitarian functioning over time. A first stance opposing the inevitability of oligarchisation endeavoured to identify these specific conditions in the characteristics of the organisation and of its structural environment. In the case of co-operatives, small size and positioning in nichemarkets that face little competition from capitalist organisations were found, for instance, to constitute facilitating conditions for organisational democracy (Rothschild-Whitt, 1976). A second stance, inspired by radical social-movement organisations, found these necessary conditions to be the devising and implementation of a set of rules and procedures that actively support egalitarian and democratic practices (Maeckelbergh, 2011; Sutherland et al., 2014). Within so-called participatory democracy, equality is ultimately achieved as the outcome of

\footnotetext{
1 This typically includes political parties, worker unions, associations, social-movement organisations, cooperatives.
} 
some formalised and continuously-improved processes (e.g. consensus decision-making) aimed at curbing power-centralising forces (Graeber, 2009; Kokkinidis, 2015).

In the present study, I draw on a piece of ethnographic work, namely one year of participant observation as a factory worker within a co-operative, to suggest a third avenue that is possibly conducive to avoiding the fate of oligarchisation within democratic organisations. It consists of naming power, embodying this in a figure, and - through mostly informal practices - stripping this figure of authority. The remainder of the paper strives to reflect the largely inductive process that I went through before ultimately formulating this proposition. I first offer a general presentation of the co-operative and of its conditions of access. Having underlined that its most striking feature consists of the presence of powerless chiefs in its midst, I propose that the works of anthropologist Pierre Clastres provide a suitable lens to help make sense of this phenomenon. Informed by this theoretical perspective, I then describe the day-to-day practices by which members of the co-operative render their chiefs powerless in effect. Finally, I reflect on how this Clastrian reading of the co-operative factory's activities contributes to our understanding of practices of equality and democracy within member-based organisations, as well as offering new avenues for studying co-operation.

\section{Factory work in the co-operative sheet-metal factory}

Scopix ${ }^{2}$ is a sheet-metal factory that is located in France and was incorporated as a worker cooperative some 30 years ago. At that time, the owner and boss of the company that then existed decided to close down the factory. The workers picketed it for several weeks until they were eventually offered the opportunity to run the business as a co-operative. After a couple of difficult years, during which employees frequently worked for no pay at the

\footnotetext{
${ }^{2}$ This name is an alias, as are the names of the co-operators.
} 
weekend in order to avoid bankruptcy, Scopix found itself in a position to support the rapid development of one of its customers, thus securing the activity and profitability of the cooperative. Scopix now comprises 25 worker-associates and has a yearly turnover of circa $€ 2.5 \mathrm{~m}$, with this customer still being its main one and accounting for nearly half its sales. Typical products include electrical boxes or cabinets, control panels and various mechanical parts, with sheets of aluminium, steel and stainless steel being processed, based on customers' technical blueprints.

The shop-floor is divided into three main sections (in order of process flow): cutting (stamping and laser cutting), bending, and welding plus assembly. All current shop-floor workers are male. Sheet-metal work is a physically demanding job, with most tasks requiring workers to stand up all day, and frequently to handle heavy and cumbersome parts. Consequently, many workers, even the youngest, suffer from chronic back problems. In addition, the shop-floor is very noisy, and some of the tasks are either dirty (due to the metal dust from grinding and deburring) or dangerous (for example, binding, where one worker cut off the tip of one finger during my time at the factory), not to mention repetitive.

All current workers are associates, except for a few trainees and temporary workers, the rule in force being that workers usually become associates after they have completed their first year of employment. The company is $100 \%$ owned by its employees, with no support from external associates ever having been needed. Scopix functions with a supervisory board (composed of three members elected by the associates for a six-year term) and an executive board (three voluntary members designated by the supervisory board for a four-year term). All three members of the supervisory board are currently shop-floor workers. While the previous executive board was composed of two functional managers (accounting and sales) and one shop-floor worker, the new board (designated in 2013) is now predominantly composed of shop-floor workers, with just one of its members splitting his time between 
office activities (programming for cutting machines) and shop-floor work (cutting). This feature - i.e. the existence of an executive board that is composed of members whose term is quite short and tends not to be renewed, and that includes lay workers - is in itself a strong marker of Scopix's distinctiveness among French worker co-operatives. Organisations of a comparable size are almost all run by a general manager who happens to be a professional manager and whose term of office often extends over a long timeframe (Bataille-Chedotel and Huntzinger, 2004; Joannidès and Jaumier, 2014). This testifies for Scopix's pronounced interest in egalitarianism, an interest that is also reflected in the limited wage-differential scale (approximately 1:2) and in the fact that profit-sharing bonuses are not defined in proportion to salaries but are distributed equally.

My engagement with the factory was as an unpaid trainee over a one-year period, from September 2013 to September 2014, filling in for various vacancies on jobs that are less demanding in terms of skills. I started with the job that is considered the most basic on the shop-floor, that is grinding and deburring, and then progressively took on others, such as tapping, milling, and plugging of metal inserts and studs. I was also able to work on the stamping and bending equipment, provided the machine had already been set up by a skilled worker. In fact, bending on a press brake soon became one of my most frequent assignments, since I apparently displayed less clumsiness in this, as well as genuine affinity for the task. My specific status also allowed me to attend as many meetings as I wished. In particular, I systematically attended the weekly meeting of the executive committee (réunion de directoire), which takes place every Tuesday after the end of the working day; during this, committee members review the main issues, make decisions, and see co-operators who wish to make complaints. I also attended all the individual interviews organised by the new executive committee at the beginning of its term so as to get feedback from the associates about their priorities. Other opportunities to engage further with my co-workers came in the 
form of lunch breaks (usually in the shared kitchen or at barbecues organised in front of the factory during spring and summer), and going out with single men of all ages at the weekend.

If conditions of access to the field are revealing of the group under study (Favret-Saada, 1980; Geertz, 1973), I must confess that my access to Scopix was surprisingly easy. It was granted, despite my presenting a rather vague objective at the time, after a single interview with one member of the former executive board, whose decision was immediately validated by her comembers on the board. And while I was afraid that the new executive board - which was designated after I had gained this agreement but before I had actually started my fieldwork might question a decision made by their predecessors, they reiterated their agreement after a brief meeting. During my stay, I was never refused the opportunity to participate in any meeting, even including those on sensitive matters (for instance, giving a warning to an associate), and most of the time was even kindly informed when an unexpected meeting was organised on the spot. Whenever I expressed surprise about my presence being so easily accepted, the recurring motto was: 'We've nothing to hide here.'

What rapidly emerged as one of the most striking features of Scopix was the presence of powerless chiefs in its midst. Within the co-operative, the organisation is admittedly formalised; as evidenced by its organisational chart, it indeed conforms to quite a classic vertical hierarchy. Scopix's managerial structure is headed by both supervisory and executive boards, and complemented at the level below by four functional managers (accounting, sales, technical and engineering managers) and a foreman who has direct responsibility for all shopfloor workers. However, this does not translate into the exertion of much power and authority by chiefs ${ }^{3}$ over subordinate workers. Membership of the supervisory board is thought of - and

\footnotetext{
${ }^{3}$ I chose the term 'chiefs', despite its being somewhat vague in English, to refer to the people whom members of the co-operative designate (similarly vaguely) 'les responsables' (literally, those who have responsibilities). In
} 
in fact functions as - a purely honorific position, mostly a measure of one's popularity among colleagues. Its three benevolent members are only marginally involved in managing the cooperative: they (at least as members of the supervisory board) exert little or no control - and have no particular supporting role in - the activities of the executive board. Although they are periodically invited by the latter to attend meetings (whenever matters of concern are discussed), they rarely deign to show up. The management of the co-operative thus rests primarily on the shoulders of the executive board. This task remains, however, mostly theoretical, as board members are not provided with the means, especially time, that would allow them to handle this task properly. Obliged to carry on with their usual work, they can dedicate only a few hours per week to attending meetings, some outside normal working hours. Unlike members of the supervisory board, members of the executive board display signs of genuine involvement, but they appear nevertheless to carry little weight in the real direction-setting of the co-operative. For instance, they have little opportunity to implement changes that are not already in line with members' wishes. Functional managers are recruited on a competence basis, appointed for an unlimited term, and given full control over their area of professional expertise. Yet at the same time, members seem to refuse to grant these functions special status within the organisation: post-holders are paid salaries that are below the market rate, and they are not allowed to use their specific knowledge to exert particular influence on the operations of the co-operative. Finally, a similar assessment applies to the foreman, who seemingly exerts little or no authority over the shop-floor workers.

How can the presence within the co-operative of largely powerless chiefs be explained? Why would an organisation appoint managers if not for them to exert authority over their

the minds of co-operative members, this usually includes the three members of the executive board, the foreman and the four functional managers (accounting, sales, technical and engineering managers), but may contextually designate one of these categories only. 
subordinates? These are some of the puzzles that I tried to solve. The works of Pierre Clastres on primitive societies were the first to conceive of a chieftainship that was in essence separated from power and authority. Therefore I interpreted my own empirical observations as an invitation to carry us away from the French co-operative sheet-metal factory to the SouthAmerican Indian tribes with which Clastres was so familiar, and thus to travel back in time from the present to the 1960 s.

\section{Pierre Clastres and the primitive societies: 'a chieftainship without authority'}

A French anthropologist, Clastres (1934-1977) studied (in his fieldwork) Indian tribes in Paraguay and Brazil, including the Guayaki, the Guarani and the Chulupi (Clastres, 2011). In one of his major works, Society against the state (1987) - originally La Société contre l'Etat $(1974)^{4}-$ Clastres shows that while primitive ${ }^{5}$ societies are indeed stateless, this absence must certainly not be interpreted as a lack, as too often suggested by an ethnocentric view that considers the state as the desirable aim for any society. Rather, this absence marks the victory of societies that in essence seek independence and thus refuse to submit to state power (Clastres, 1987, 1994; see also Scott, 2009 for a Clastrian perspective on another geographic and historic context).

Besides this objective of external policy, i.e. to preserve their independence, primitive societies have a second political objective, one of internal policy, which is to preserve their social homogeneity:

\footnotetext{
${ }^{4}$ The book is actually a collection of articles previously published through various outlets, such as Critique, L'Homme, Les Temps Modernes and L'Ephémère.

${ }^{5}$ In casually referring to 'primitive societies' and later on to 'Savages', I choose to be faithful to Clastres' own words, upon which he was of course conferring a highly ironic tone, since the key aim of his work was to show just how elaborate the functioning of these societies (especially their political system) actually was.
} 
The same rigorous logic determines both the internal policy and external policy of primitive society [...] the community wants to persevere in its undivided being and prevent a unifying authority - the figure of the commanding chief - from separating itself from the social body and introducing social division between Master and Subjects. (Clastres, 1994: 165)

Thus, what Clastres studies are the means by which primitive societies have prevented the emergence of a central authority, allowing only the "bizarre persistence of a "power" that is practically powerless, of a chieftainship without authority, of a function operating in a void' (Clastres, 1987: 29). So why have a chief then? Because Indian societies have decided that power is better kept at bay by being named and embodied in the figure of a chief, rather than simply by being ignored:

For, on discovering the great affinity of power and nature, as the twofold limitation of the domain of culture, Indian societies were able to create a means for neutralizing the virulence of political authority. They chose themselves to be the founders of that authority, but in such a manner as to let power appear only as a negativity that is immediately subdued: they established it in keeping with its essence (the negation of culture), but precisely in order to strip it of any real might. Thus, the advent of power, such as it is, presents itself to these societies as the very means for nullifying that power. (Clastres, 1987: 44-45)

The sole exclusive privilege that is usually recognised to the Indian chief is that of polygamy (Clastres, 1987: 32). In return, the chief must provide the group with goods and words, being generous with possessions (seldom being able to reject the relentless requests emanating from the group) and with speaking (thus being expected to be a good orator). Notwithstanding the fact that the words of the chief may be meaningless and often not even listened to, they are 
nonetheless demanded (Clastres, 2000). As Clastres puts it, 'if in societies with a State speech is power's right, in societies without a State speech is power's duty' (Clastres, 1987: 153). Within primitive societies, these elements of the cycle of exchange are of utmost importance for annihilating the power of chiefs. For instance, the 'obligation to give, to which the chief is bound, is experienced by the Indians as a kind of right to subject him to a continuous looting' (Clastres, 1987: 30). In a similar vein, 'the chief's obligation to speak, that steady flow of empty speech that he owes the tribe, is his infinite $\mathrm{debt}^{6}$, the guarantee that prevents the man of speech from becoming a man of power' (Clastres, 1987: 154-155).

What Clastres makes eventually visible through his study of South-American Indian tribes is the Savages' 'continual effort to prevent chiefs from being chiefs' (Clastres, 1987: 218), understood as a means of maintaining the homogeneity of the group. He points out that the political goals of primitive societies, namely their independence and the homogeneity of their social body, can be met only because relentless work goes on in the group to put power at bay. Turning back to Scopix, the French co-operative sheet-metal factory, I thus similarly tried to appreciate the kind of activities that were performed by its members so as to prevent the locus of chieftainship being confounded with that of power.

\section{Preventing chiefs from being chiefs within Scopix}

Three types of daily activities appear as central for members of the co-operative to avoid the coalescence of power in the hands of its chiefs. First, co-operators relentlessly voice their refusal of a divide between chiefs and lay members. This contributes to reaffirming a group culture in which there is limited room for hierarchical power. Second, co-operators express permanent criticism and requests for accountability towards chiefs. This puts them in infinite

\footnotetext{
6 'Debt' is used to mean the (purposeful) creation of an imbalance in the cycle of exchange (symbolic and/or material) between chiefs and members. The debt is said to be 'infinite' because it can never be settled.
} 
debt towards members, a situation that conspicuously contradicts their exerting power. Third, co-operators use schoolboy humour to undermine chiefs' credibility and to limit their claims to authority.

\section{Refusal of the divide}

The first type of activities performed by co-operators to prevent chiefs from being chiefs is relentlessly to voice their refusal of a divide between chiefs and lay members. In this sense, it can be said that co-operators share a political objective that is similar to that of primitive societies, namely preserving the homogeneity of the group. One of the most visible activities aimed at doing just that lies in the daily interactions between shop-floor workers and chiefs. It is quite common to hear the former reminding the latter that they are ultimately all associates, and thus need to be considered on an equal footing. The following exchange, which took place during the individual interview with Raymond ${ }^{7}$, an operator from the cutting section, is illustrative of such practice:

Olivier, member of the executive board: When Bernard [the workshop foreman] gives you a command, you ...

Raymond, interrupting him: I am not given commands; I'm an associate here!

Olivier: Uh ... well, I mean ... uh ... when you are provided with some work instruction by Bernard, you ...

The shop-floor worker actually made the member of the executive board reframe his sentence, thus producing a periphrasis that now partly conceals the hierarchical relation that is supposed

\footnotetext{
${ }^{7}$ I here refer to the individual interviews organised by the new executive committee at the beginning of its term so as to get feedback from the associates about their priorities.
} 
to link him with the foreman. While I had thought, at the very beginning of my fieldwork, that this kind of behaviour was the privilege of senior workers - although Raymond is quite young, he has been working at Scopix for more than ten years and is clearly identified as one of Scopix's 'loudmouths' - I rapidly came to realise that less senior workers could engage in similar practices. Once, while I was milling alongside Marc, a rather discreet worker, he replied to the foreman's multiple requests as follows:

Marc, with a slight smile and speaking in a pleasant tone: Don't start playing the boss, Bernard ...

Bernard, also pleasantly but with a slight touch of exasperation: I am not playing the boss, I AM your boss!

The conversation ended up with Marc confirming that he would proceed as per Bernard's requests ('I'll take care of it'), but enunciating this in a tone that conspicuously meant that he would be doing it only because he himself was willing to do it, as if he were doing Bernard a favour.

The affirmation of the refusal of the divide between chiefs and lay members may also take a playful form. At times, I could hear shop-floor workers shouting out to each other:

Worker A, shouting with a carefully studied varying pitch: WHO is the BOSS?

Worker B, in the same manner: It's ME! I'M the BOSS!

As a consequence of its frequent occurrence, I eventually asked who had initiated this game, which I took to be a private joke based on some past work event. I was in fact referred to a well-known TV commercial (I do not watch much television, which explained my ignorance) by a car rental company, where superior service is supposed to put the customer in the boss's 
shoes $^{8}$. When playing this game, members of Scopix are merely reminding each other of a basic co-operative principle, i.e. everyone is a boss in such an organisation, since everyone has ownership. However, this takes a particular flavour in the case of Scopix, insofar as it leads lay members frequently to oppose the claims for authority put forth by chiefs. One day, I heard a nearby worker playing the game by himself, saying out loud, 'WHO is the BOSS? It's ME! I'M the BOSS!' while on the job, which made me smile. However, I could not help thinking that this was probably not simply the meaningless by-product of the performance of a very repetitive task (see Roy, 1959), but also a way to make sure, by ritually repeating it to oneself, that something essential would not be forgotten, i.e. the refusal to accept that the group be divided into those who command and those who obey.

Another telling episode, which is very significant in terms of how the refusal of the divide between lay members and chiefs may be expressed, relates to the management of functional managers' extra hours. During 2013, all office workers started to clock in as a result of the pressures emanating from the shop-floor in favour of such move. While it had, until then, be considered technically too difficult to implement clocking-in for office workers because of their non-standardised schedules, this was contested by a few shop-floor workers, who issued a petition arguing that they could not see why they themselves should clock in if some associates did not have to do so. This forced the executive board of the time to organise a consultation, in which a majority of associates supported clocking-in for all. Unsurprisingly, when a first assessment of the new system was made at the end of 2013, all functional managers happened to be credited with a huge number of extra hours. I was thus offered the opportunity to attend a rather tense meeting, during which the new executive board, unwilling to authorise these extra hours to be paid, proposed that the functional managers should 'wipe

\footnotetext{
${ }^{8}$ To see the commercial with English subtitles: http://www.youtube.com/watch? $v=$ sulaJIjwgGI
} 
the slate clean' for the past year and make sure from then on that they could stick to their 35hour week contract. Functional managers violently opposed having their hours written off:

Pierrick, engineering manager, very annoyed: What?! Are you taking the piss out of us? For more than seven years now, I have performed hundreds of extra hours without claiming any extra pay. We are not the ones who asked to clock in. They [the shopfloor workers] asked for it, so now they have to suck it up!

If one considers this episode from an economic perspective, it is simply incomprehensible. What is the point of asking managers to work shorter hours when they have, until now - for more than ten years, in the case of the most senior - systematically accepted working overtime without claiming any extra pay? From the erroneous perspective of utilitarian calculation, I myself at first read the whole exchange as an expression of the co-operators' taste for creating problems where there initially were none. However, once one seriously accepts that Scopix follows not only economic objectives but also political ones - of which the primacy is regularly recognised - the story no longer appears as an anomaly. Once one accepts that the co-operative is in essence defined by its will to avoid having the chiefs separating from the social body and thus introducing division into the group, the discourse of the executive board becomes transparent:

Michel, member of the executive board: I see no reason why you would need to work more than 35 hours a week. No one is indispensable. Your working contract is for 35 hours! So we understand that you may need to do some extra hours to deal with some unevenness in your workload from time to time, but these hours should eventually be recovered. If you are shown to be doing extra hours in the long run, this means that we are badly organised and that something has to be changed. 
As can been seen through these examples, the relentless efforts aimed at preserving the homogeneity of the group are mostly accomplished by shop-floor workers and directed towards chiefs. They can also, as in the case of the clocking-in, be found among the executive board, directed at functional managers, or vice versa. These practices contribute to constantly reaffirming a group culture where there is, in the end, limited room for power to be exerted by the hierarchy. Indeed, chiefs know that any action or wording that would too conspicuously testify to their authority runs the risk of immediately being contested. And consequently, they know that they have a better chance of meeting their objectives when these already match the objectives of the shop-floor workers, and that the task of convincing the latter cannot be overlooked where this is not yet the case.

\section{Overt critique and requests for accountability}

A second dimension in the work performed by members of Scopix to prevent chiefs from being chiefs consists of submitting them to permanent criticism and requests for accountability. These activities are especially visible when it comes to the executive board. As soon as its members get to the shop-floor after leaving a meeting, workers tend to ask them about the outcomes, demanding that they justify the decisions taken, which are criticised whenever they do not match workers' own views. When topics deemed very sensitive are at stake, such activities multiply. For instance, one day, the realisation that a regular bonus had been awarded by the previous board to one of their co-workers triggered some frenetic criticism from workers who considered it undeserved, the worker concerned being said not to fulfil the tasks that initially served to justify the bonus award. Although board members were in this case simply inheriting a problem that they had not themselves contributed to creating, they were subjected to a relentless flow of questions and criticism, demanding that they justify either why they had not yet suppressed such an unfair bonus or, conversely, why they 
intended to suppress someone's acquired benefit. I could see that operations were seriously disturbed during that day, at the end of which Kevin, the youngest member of the board, uttered with a sigh: 'I feel like I spent my entire day answering their questions.'

Interestingly, I regularly observed that being sure of the facts was not a prerequisite for members' criticism of chiefs. For instance, in the example of the worker's bonus mentioned above, I could hear some workers criticising the board for having suppressed the bonus, although I knew the decision was still pending. Consequently, in a lot of cases, when the board was coming under attack, its job was mostly about re-establishing the truth. Since I had noticed that the board was quite transparent, providing members with the available information when requested, I first wondered why workers did not simply question board members more systematically when they wanted to know something. I came to realise that, from the co-operators' perspective, this was not necessarily desirable, because what mattered to them was first and foremost the act of criticising, independently of its content. Limiting oneself to solid information would tend only to limit the range of criticism available to them. I received some level of confirmation of this interpretation when asking members of the executive board why they did not organise some brief ad-hoc information meetings on the shop-floor in order to avoid the diffusion of gossip. They smiled at each other, so underlining the naivety of my question, before one of them replied:

That would not change anything. Even at the Annual General Meeting, you can see that no more than five minutes after the end, there is already some gossip going on.

Indeed, I noticed, for instance, that the minutes of the weekly executive-board meetings, which are posted close to the coffee machine, were seldom read. While one could conclude from this that criticising is, for Scopix members, an end in itself, such a conclusion would in fact be inaccurate: rather, it is one of various means that co-operators use to limit chiefs' 
power. Indeed, the continuous flow of criticism and of requests for accountability that targets the board members keeps them alert not to go beyond their mandate. For instance, at the end of his individual interview (with the new executive committee, to get feedback from associates), Roger (who works in delivery) continued his discussion with the board for some time. As one of the most senior workers, Roger was keen to insist that 'executive-board members [had] always been spared within Scopix' and that they were always given some scope to act in accordance with their own personal interests. Although I cannot testify to the situation when previous boards were in place, I found his statement astonishing with respect to my own observations of the current board and its relations with other members. In stark contrast to Roger's view, what I found very striking was the cautiousness displayed by board members in avoiding any decision that may arouse the least suspicion of seeking to favour themselves - including a case where extending the responsibilities of one of the board members, although seemingly the most logical solution to the problem at hand, was dismissed. I interpret this cautiousness as a direct result of the pressurising activities exerted by co-operators, as previously described. In this sense, Roger's comments are probably best understood as if he were describing not what was happening but rather what should not happen - and, by so doing, contributing to having the threat of which he warned more surely averted.

Besides the executive board, other chiefs can be similarly targeted by this continuous work of criticising and demanding accountability. Raymond, one of the workers from the cutting section, who had repeatedly had arguments with the foreman in the preceding weeks, eventually decided to join the executive board's weekly meeting in order to reiterate his grievances. He started by mentioning that he would raise only things that he had already directly complained about to the foreman ('I've told him already'), thus making it clear that what he was looking for was, above all, some sort of arbitration in his favour. He then 
complained that the foreman was always 'on his back' and constantly making 'digs' at him in order to detract from the perceived value of his work. He asked for a daily schedule to be provided to him so that he could work in an autonomous way, instead of being repeatedly bothered by the foreman's changing priorities. Finally, he criticised the board for taking sides too often with the foreman and stated that he was speaking not only for himself but for his entire section. Having talked for some 30 minutes, almost without being interrupted, he looked at his watch and suddenly stood up: 'F***, it's already $5.40 \mathrm{pm}$ ! My wife will kill me!' He hurried out of the room, only to poke his head back round the door to proclaim his conclusion: 'In short, he'd better stop pissing me off!'

If members of Scopix appear to be more afraid of their wives than of their chiefs, this is probably because their experience suggests that it is in fact easier to have the upper hand with the latter. On the day after Raymond's intervention at the executive-board meeting, I worked all day within his section and could hear him trying at length to convince his co-workers of the foreman's mistreatment of him and others, as well as conveying his mistrust of the executive board. At that stage, I realised that Raymond's lobbying echoed his mates' concerns only partially, and that he had been getting a little ahead of himself when claiming, the day before, that he was expressing the general opinion. However, when such lobbying does more closely reflect the feelings of the shop-floor workers, it has genuine consequences. Bernard, the current foreman, had in fact already occupied the position for some time, in the past. Having been found too authoritative by his former co-workers (he was previously a welder), he was dismissed by the board from his foremanship after a majority of workers opposed his holding the position, and he returned for a time to his welding job. He owes his recent comeback, one of the founding decisions of the new executive board, to his recognised technical skills and strength of character, but the negotiations required him to promise that he would adjust his leadership style to be more consensual. While Raymond has probably 
developed too much enmity on the shop-floor to be able to leverage existing discontent against Bernard, other pockets of resistance still exist in the factory and may succeed in doing so in the future.

This symbolic murder of the chief is reminiscent of the actual murders that were sometimes perpetrated against primitive chiefs who tried to exceed their roles (Clastres, 1994: 91, 170; see also Leach, 2004[1964]). Clastres reports the tragic end of one of them:

They killed him in the middle of the square around which the village is built, the shelters. They killed him, all of them. I was told he was run through by perhaps 30 arrows! That is what they do with chiefs who want to play chiefs. In some cases, they turn their back on them, that is enough. If not, they wipe them out, once and for all. (Clastres, 2012: 47, own translation)

Like the foreman, the executive board knows that its term - theoretically of four years - may come to an end more rapidly than planned if it dissatisfies Scopix members too much. This has not happened so far, all executive boards having been allowed to complete their term. Still, while Scopix's co-operators are offered the opportunity to demonstrate their support for the board each year through a show of hands at the Annual General Meeting, they have not done so: the vote has been consistently negative in recent years. Although a negative vote is not expected to lead automatically to the resignation of the executive board, it contributes to reminding its members that they are permanently at the mercy of their co-workers.

In addition to potentially leading to some concrete changes in the organisation chart, the relentless overt critique and demands for accountability expressed by co-operators have a more immediate effect. They place chiefs under constant pressure, in a position reminiscent of that of Clastrian chiefs, i.e. their owing an infinite debt to the group, a debt that is never supposed to be fulfilled. The constant flow of overt critique that members of Scopix direct at 
their chiefs is comparable with the constant looting by Indians of their chiefs' possessions. The endless requests for accountability that subject Scopix chiefs to futile justification is similar to Indians' requirements for primitive chiefs to talk, in both cases reversing the dominant belief that speech would be 'power's right' instead of 'power's duty' (Clastres, 1987: 153). And in both cases, form is actually more important than content: in primitive societies, chiefs' speech can at times be empty and fail to convey any meaningful content; at Scopix, criticism again does not always take issue with real facts. What matters most is simply that the flow of speech or critique be sustained, thus indefinitely reaffirming the infinite nature of chiefs' debt ${ }^{9}$.

Within Scopix, this state of affairs may be tough to experience. While the current foreman is mentally resilient and has the advantage of knowing the tricks that he himself long performed as a shop-floor worker, his two immediate predecessors left the company, the first due to burn-out and the second to being systematically played and cheated by workers. Consequently, when chiefs meet other chiefs, their talks may sometimes be more evocative of group therapy than of an exchange between self-confident managers:

André, technical manager: I feel totally isolated within the company.

Olivier, member of the executive board: And what about us? Don't you think we feel isolated as an executive board?

One Tuesday evening, around $8 \mathrm{pm}$, the executive board was continuing its weekly meeting through talking on the pavement in front of the factory, despite the darkness and bitter cold. Its members had had a particularly hard day, and I could sense a lot of weariness and

\footnotetext{
${ }^{9}$ The extra hours worked by functional managers, as long as they were freely given, could also be understood as resulting from the debt that chiefs owe to members of the co-operative. However, once paid, these hours would lose this meaning and instead appear as an unacceptable display of power - hence their rejection by co-operators.
} 
despondency in their exchanges. To conclude, Olivier expressed in a striking manner a feeling that is widespread among Scopix chiefs:

One is used to speaking about harassment in relation to an employee. But shouldn't it be possible to speak about harassment in relation to an executive board too?

\section{Schoolboy humour}

The third important dimension that is revealed when studying co-operators in their constant effort to prevent chiefs from being chiefs is their use of humour. In order to convey the meaning attached to such practices, I will draw on two examples.

The first of these two stories was initiated when André, the technical manager, proposed that a small office be installed behind one of the press brakes, so that Gaël, the operator running it, did not have to keep going up to the second floor to access the software needed to modify a blueprint manually. The change necessitated installing a desk and two dividing walls, and moving the desktop computer from the second to the shop-floor. Gaël was himself very supportive of the idea, but the executive board eventually chose not to follow it up, deciding that there were more urgent priorities on which to spend the several hundred euros, and maybe also fearing that the computer could be used by workers for purposes other than work.

To make a joke of the situation, Paul, one of Gaël's bending mates, decided to install a fake office in the intended place. He put a wooden plank on two stands, which he covered with a calendar, to look like a desk blotter. He then found a rejected steel part that was a similar shape to a computer screen, and brought in one of the plastic chairs used for the summer barbecues, with its blue cushion. Finally, to put the finishing touches to his work, he added a fan, a small name card with 'ANDRE' written in red, and a sheet of cardboard to form the front of the desk. On the wall behind the desk, he hung a large cardboard sign, saying 
'TECHNICAL DESK - MR GAËL' (see Picture 1). The installation triggered a lot of amusement on the shop-floor, the quality of the craftsmanship and the attention to detail being particularly praised. Gaël, despite being the butt of the joke, acknowledged that it was an excellent one. I did not witness André's reaction, but (from what I was told) the joke brought about a hollow laugh.

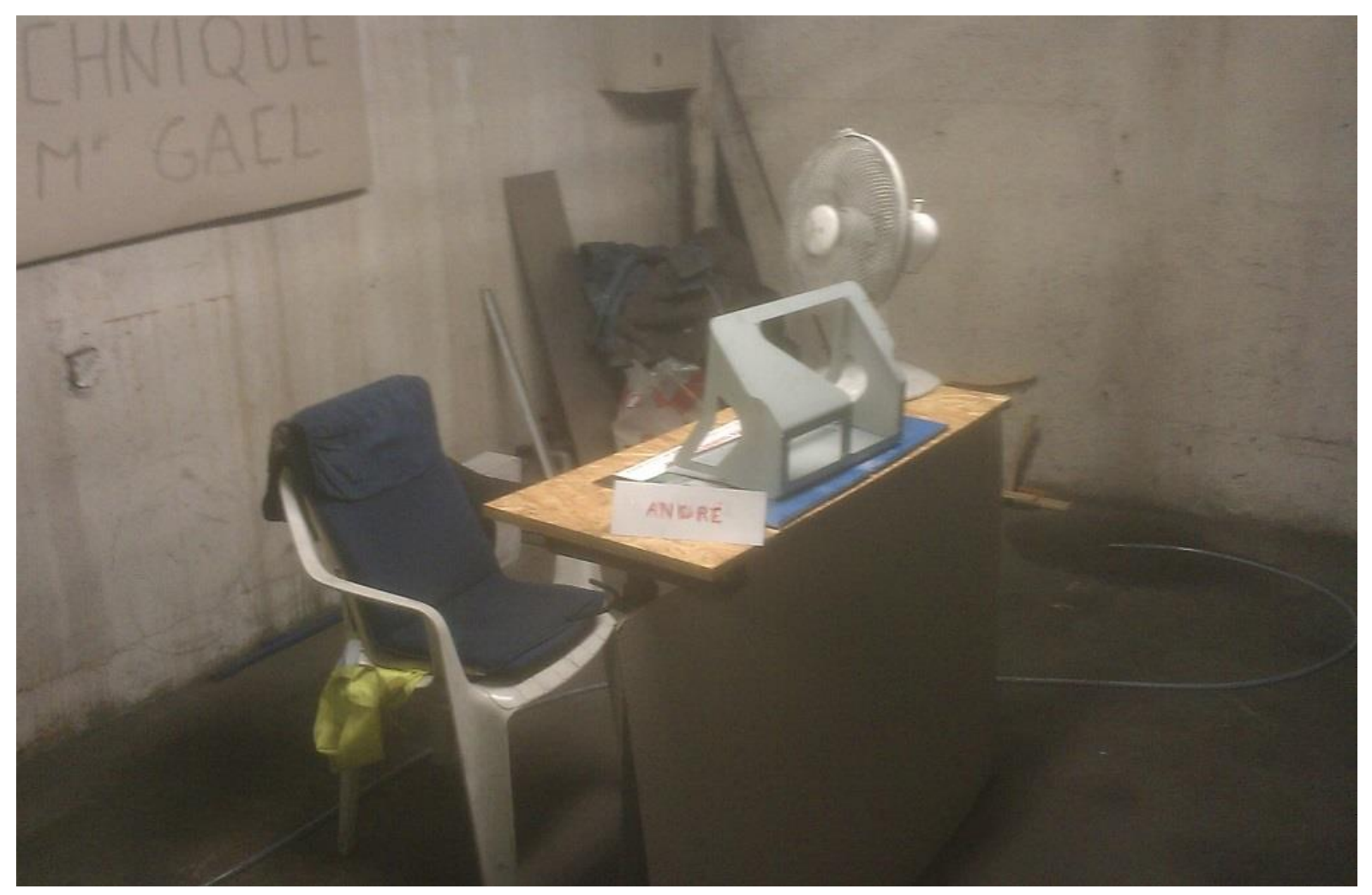

\section{Figure 1: Fake technical desk crafted by Paul}

The installation remained there for approximately two months, with none of the chiefs asking for it to be removed. When I realised one day that it had disappeared, I asked Gaël what had happened and he told me:

It was Paul and me who decided to remove it, like a couple of weeks ago. We just thought it did not really look great for customers.

Humour was used to mock not only the impeded fate of André's idea but also the executive board's refusal. During one lunchtime in the shared kitchen, in the presence of Olivier (a 
member of the executive board), the following conversation occurred. It had been a week of high absenteeism (through both holidays and sick leave), in the run-up to some departures:

Régis: If this goes on, we will end up having more office workers than shop-floor ones!

Gaël, very proud of his joke: That certainly won't happen. I recently asked for an office and it was refused by the board.

Olivier simply gave a forced laugh. This interaction shows how two dimensions of lay members' activities aimed at preventing chiefs from being chiefs tend to combine, humour often being intertwined with criticism (for related observations, see also Collinson, 1992; Korczynski, 2011; Rodrigues and Collinson, 1995). This appears to be a very powerful weapon, the use of humour preventing chiefs from responding properly to the critique unless they themselves think up a better joke with which to gain the upper hand.

During my fifth month at Scopix, I was myself involved in the second story that illustrates best how co-operators use humour to ridicule managers at times. That morning, I was working on the stamping machine, one of the jobs that I personally considered the most tedious, since the machine (in addition to being the noisiest on the floor) makes the ground vibrate unpleasantly. Besides loading up the metal sheets and unloading the parts and the sheet skeleton, there is not much to do while the machine runs, but the presence of a worker is required in front of the machine to intervene in case of a problem. André, the technical manager, came to greet me and noticed something was wrong: 
André: On these parts, you are supposed to remove the burrs in masked time ${ }^{10}$ as you go along. Didn't they tell you?

Me: Uh ... no, I didn't know ...

The two workers posted nearby, Loïc and Edmond, came over to us right then, perhaps because they were curious about what was going on. (For accuracy, I mention that they both happen to be members of the supervisory board, but am certain this had no influence on what happened.) The following conversation ensued:

André, addressing them: Didn't you tell him that he is supposed to work in masked time on these parts and start removing the burrs as he goes along?

Loïc, with an incredulous smile: What?! Come on, André! It only takes a minute to remove all the burrs at the same time at the end. With a grinder, it will take no more than a minute; it makes no sense to do it as you go along. I don't think we're that tight for time at Scopix. If we were, we'd know by now!

During the exchange, Edmond, the second worker, had remained silent but expressed his agreement with Loïc through facial expression and gestures. A little vexed, André did not insist and left. The following morning, when I was again working on the stamping machine, Edmond came up to me, closely followed by Loïc, and offered me a mask he had cut from a sheet of cardboard (see Picture 2):

Edmond: Look, this way you will be able to work in masked time!

\footnotetext{
${ }^{10}$ Working 'in masked time' means performing some operations (here, deburring) in parallel to those performed by the machine, so as to increase productivity.
} 
Loïc, appreciative of Edmond's sense of humour: Eh, have you seen our President?!

[Edmond is sometimes called Président by some of his co-workers, because he is the only remaining worker who was there at the inception of the co-operative, and he has also been a member of the supervisory board for a long time.]

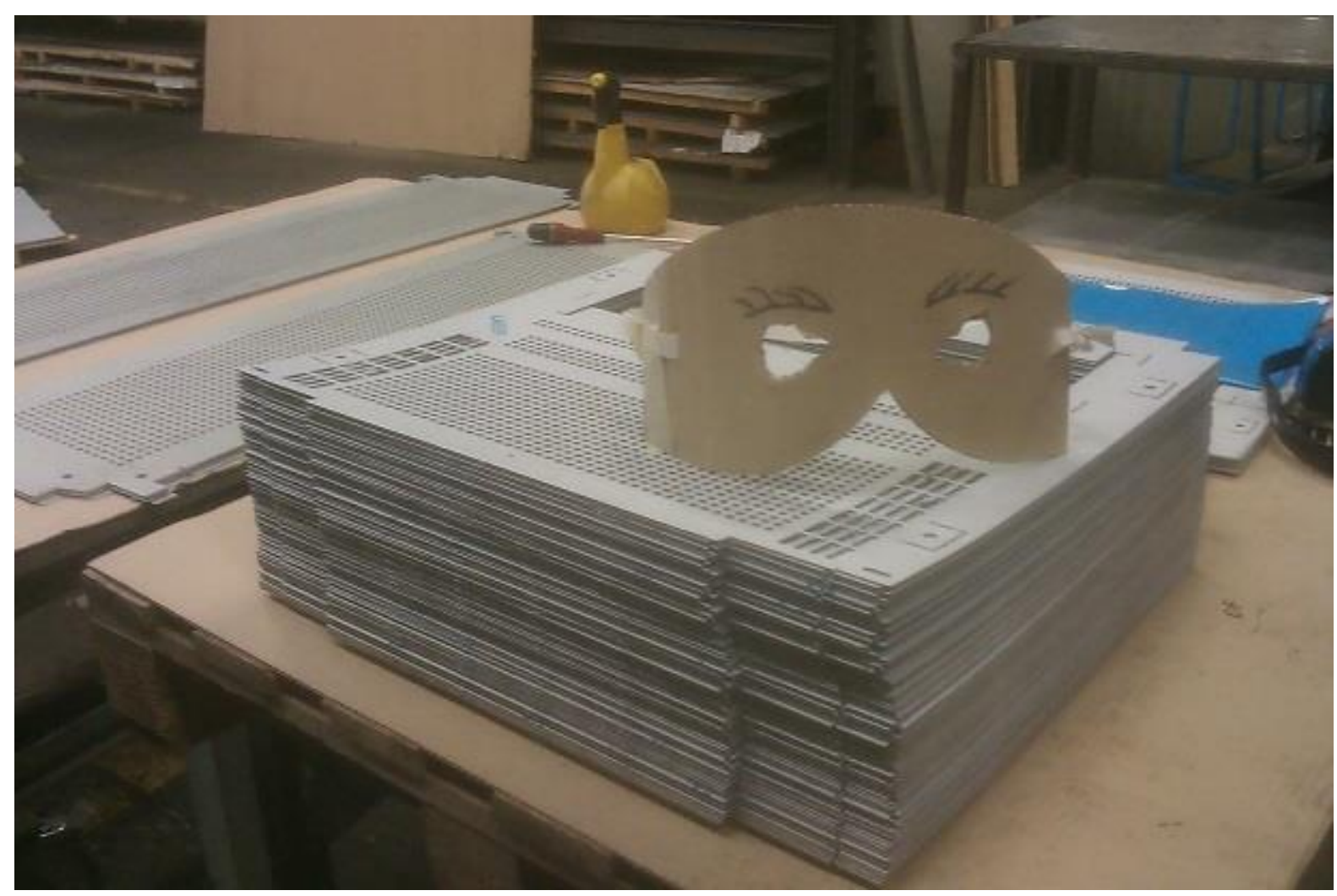

Picture 1: Mask crafted by Edmond, lying on top of a pile of parts

I tried to put the mask on my face, but broke the lashing, which was a bit too small. While I was thinking that this would put an end to the game, Edmond in fact returned in the afternoon with the repaired mask, the length of the lashing being now right for my head. I wore it for 15 to 20 minutes (I had to remove it, because it was dangerously narrowing my focus when loading and unloading) and must admit I did not feel any reluctance in doing so; it seemed the natural thing to do in response to the invitation. In particular, the fact that Edmond had taken the trouble to repair it provided a clear indication that any attempt to escape the game would lead to some disappointment. My intuition was right, and the sight of the mask provoked 
some frank laughter from workers passing by during the time I wore it. It so happened that André was not among them, but it was nonetheless clear that he was also an (or even the main) intended witness of the scene.

An outsider's eye may easily downplay such ritualistic games, but the reactions that followed left little room for doubt that these are important markers of Scopix's culture. Several workers, including the foreman and a member of the executive board, said to me with a broad smile: 'Now, you're ready to become a permanent here.' While it lasted, joining in with the joke made me a native. On the following days, another worker, Aziz, started to laugh every time we went past each other on the shop-floor ('Ah, ah, the masked time! Very good!'), and

called me either 'the masked time' or 'the masked avenger' on and off for several months. This does not mean that this cultural feature is not contested within Scopix, its childish characteristics being rejected by some. One worker with whom I had a good relationship told me:

My poor Stéphane! I like you very much, you know. It's not too late yet; you don't need to become like them.

Although he used a tone that was only half serious, I could detect traces of genuine concern in what he said. But still, the fact that he felt the need to contest this cultural frame is yet another testimony to its importance. In the mask joke, it was not only the manager who was mocked but also the managerial discourse, which - through the pun on 'masked time' - was deconstructed. The real status of managerial words is suddenly revealed: that is, empty exhortations with no impact on the reality of the shop-floor. Through schoolboy humour, cooperators thus succeed - in one fell swoop - in undermining the credibility both of chiefs and of their favourite means of exerting power.

\section{Practising organisational democracy, equality and co-operation}


The case of Scopix, as analysed through a Clastrian lens, advances our knowledge of the practices of democracy and equality within member-based organisations, such as worker cooperatives. Indeed, it shows how power can be kept at bay by being named and then embodied in a figure, who is eventually - through mostly informal practices - stripped of all authority. In addition, it suggests that our understanding of co-operation could be greatly improved if researchers' dominant focus on governance was complemented by studies anchored in the everyday experience of co-operators.

\section{The 'iron law of oligarchy' and related degeneration theses}

For a long time, the literature on organisational democracy has been dominated by Michels' pessimistic theorising of an 'iron law of oligarchy', which he derived from his observations of the evolution of political parties - primarily the German socialist party - and worker unions of his time (Michels, 1915). According to the 'iron law', member-based organisations cannot prevent the progressive realisation of oligarchic tendencies in their midst. Michels provides two main reasons for this: first, organisational members are naturally inclined to rely on some forms of charismatic leadership; and second, the existence within each organisation of technical requirements leads to the emergence of experts who capitalise on their knowledge to acquire power. Such elites, once they have emerged, then reproduce themselves, so contradicting the democratic and egalitarian ideals that are supposed to inhabit the organisation.

Within the literature on co-operatives, the concept of degeneration has served to mirror that of the 'iron law of oligarchy' (Bakaikoa et al., 2004; Cornforth et al., 1988; Storey et al., 2014; Webb and Webb, 1914). In comparison with that of other types of member-based organisations, the sensitivity of co-operatives to oligarchisation processes is aggravated by their engagement in market activities, which results in their being exposed to economic and 
social pressures from a predominantly capitalist environment (Webb and Cheney, 2014). This situation is further conducive to, inter alia, the degeneration of co-operative (including democratic and egalitarian) values, since co-operatives may progressively align all kinds of organisational routines and processes with dominant capitalist patterns in order to meet requests - sometimes genuine and sometimes imaginary - from their market environment (Cheney, 1999; Flecha and Ngai, 2014; Kasmir, 1996; Simons and Ingram, 1997; Warhurst, 1996b).

For a long time, the 'iron law of oligarchy' and related degeneration theses seem to have discouraged any serious academic contention about the possibility of genuine organisational democracy. Instead, the only questions pending have been how long it takes for the effects of this law to be realised, and what factors may possibly alter the pace of this process (Cathcart, 2013; Mansbridge, 1983; Meister, 1984; Piven and Cloward, 1979). In particular, evidence has been provided that the actions of merely removing centralised power structures and ordaining a ban on anything that resembles an organisational hierarchy do not work as miracle cures in getting rid of issues of power. These beliefs, which are nowadays considered largely naïve, were widespread among social movements of the 1960s; various failed experiments were needed for such movements to make sense progressively of the threats associated with the outright rejection of any formal organising (Maeckelbergh, 2011). Drawing on her activist experience within feminist movements, Freeman (2013[1972]) evokes a 'tyranny of structurelessness' to characterise the looming evils for organisations that associate democracy and equality with alleged organisational flatness. She observes that the void created by the absence of any formally legitimated hierarchy invites the most active and competent clique to pre-empt responsibilities and constitute an informal elite (see also Diefenbach and Sillince, 2011). The effects of an informal hierarchy are usually more perverse than those of a formal one, because they are more difficult to identify, control and oppose. In Freeman's terms, 
structurelessness does not abolish power; what is in fact abolished is the opportunity to require those who exercise power (informally) to be accountable for how they make use of it. In the case of co-operatives, this is exemplified by numerous cases in which radical experiences of self-management have progressively turned sour and in the end displayed harsh patterns of domination (Georgi, 2003).

\section{Challenging the 'iron law'}

In view of this, challenges to the 'iron law' have progressively integrated the idea that specific conditions needed to be present for democratic organisations to have a chance of retaining their egalitarian functioning over time. A first stance has striven to identify these conditions through specific characteristics of the organisation and of its structural environment. Small size, favourable local political context, and (in the case of co-operatives) positioning in nichemarkets that suffer little competition from capitalist organisations have all been found, for instance, to constitute facilitating conditions for organisational democracy (Rothschild-Whitt, 1976, 1979; Schneiberg et al., 2008; Varman and Chakrabarti, 2004; Zald and Ash, 1966).

A second stance, inspired by radical social-movement organisations, found the necessary conditions to be the devising and implementation of a set of rules and procedures that actively support egalitarian and democratic practices (Maeckelbergh, 2011; Sutherland et al., 2014). The lesson drawn from the misguided experiences of the 1960s was that the will of members of democratic organisations to free themselves of power relations was illusory and even noxious. Rather than being abolished, power had to be acknowledged and channelled in ways that were compatible with democracy and equality (Mouffe, 1996). The option that was developed lay in the elaboration and practising of a constantly improved 'set of rules and procedures that guide and structure the process of democratic decision-making' (Maeckelbergh, 2011: 304). Ethnographies of anti-globalisation activism - such as Graeber's 
Direct Action (2009) and Maeckelbergh's The Will of the Many (2009) - describe at length, from the inside, the ways in which democracy and equality are actively produced and maintained in these settings (see Sutherland, 2013 for a review). Consensus decision-making is favoured over majority voting so as to include everyone's voice equally in the process (Seeds For Change, 2013). At the same time, the persistence of inequalities - whether gender, race-, class- or skill-based - is considered inevitable and is addressed as much as possible through ad-hoc curbing techniques (Graeber, 2009). Similarly, other techniques aim to ensure the rejection of all forms of representation and a continuous fight against power-centralising forces. In the end, participatory democracy turns out to mean a learning process in which activists come to regulate their behaviour and become active participants in the construction of equality (Maeckelbergh, 2011). Rather than as a point of departure, horizontality (i.e. the absence of hierarchy) is thus best envisaged as an outcome (in constant need of actualisation) of this process, and of the rules and procedures that support it. If forms of leadership are still likely to emerge, they are now of a collective kind; it is a leadership without leaders (Sutherland et al., 2014).

Because they have engendered massive mobilisation and media coverage, social movements such as Occupy Wall Street, Los Indignados and, more recently, Nuit Debout have contributed to offering some broader public visibility to such democratic and egalitarian procedures (Hardt and Negri, 2011). However, their translation from social movements to other types of member-based organisations is far from being straightforward, and how this is best realised needs to be further documented (Land and King, 2014). With respect to cooperatives, Kokkinidis' (2015) study of self-managed worker collectives in Greece provides a compelling illustration of how those principles can be adapted to economic activities. In the settings he observes, direct democracy and horizontality characterise decision-making processes, which are consensus-based. But they also similarly permeate all kinds of working 
and organisational practices - supported by various rules (e.g. forbidding the hiring of temporary staff) and procedures (e.g. using job rotation as a way of developing collective knowledge) (see also Cornforth, 1995; Hunt, 1992).

\section{An alternative way to resist the 'iron law': the Clastrian perspective}

To sum up, one possible way to channel power in a manner that is compatible with equality and democracy consists of putting into practice a set of rules and procedures that offer constantly vigilant opposition to power-centralising forces and to the emergence of individual leadership. I now want to contend, based on Clastres' thinking and its application to the case of Scopix, that another possible way to generate equality within member-based organisations consists of naming power, embodying this in a figure, and eventually stripping the figure of any authority. Unlike previously, when power was kept at bay by being refused any chance of personification, it is now kept at bay by being given a name and a face. Whereas direct democracy was given primacy, a simulated form of representative democracy is now staged. And while equality was an effect of constantly fine-tuned rules and procedures, equality is now achieved through the routinised practices of members to which their egalitarian culture gives way.

Within the stateless societies studied by Clastres $(1987 ; 1994 ; 2000)$, avoidance of the fate of oligarchisation sounds to be the outcome of day-to-day practices relentlessly performed by members and aimed at preventing those whom they have appointed to chieftainship from acting as real chiefs. While equality may for a time appear to be threatened by the existence of a commanding figure, it is actually preserved in practice because any power display is immediately curbed and any attempt at self-assertion similarly tackled by all sorts of levelling practices. Ultimately, the group remains the real locus of power; chieftainship can never be more than a locus of prestige (Clastres, 1987: 206-208). American anthropologist Christopher 
Boehm has found repeated clues that the organisational model evidenced by Clastres in South-America (together with the corresponding practices and supporting mechanisms he analysed) was in fact widespread among societies of both hunter-gatherers and tribespeople on all continents. He uses the term 'reverse dominance hierarchy' to characterise this model, in which power is collectively present at the bottom while lacking at the top (Boehm, 1993). In this, equality and hierarchy are no longer opposed; rather, the latter is the means by which the former is attained: 'egalitarianism is in effect a bizarre type of political hierarchy [in which] the weak combine forces to actively dominate the strong' (Boehm, 1999: 3).

In providing the theoretical underpinning of reverse dominance hierarchies, Clastres also emphasises that the primary determinant for the persistence of egalitarian practices is to be found neither in favourable structural conditions nor in the formal rules that the organisation gives itself (Clastres, 1987, 1994; also Boehm, 1993: 227). What is instead central is that equality be constituted by the group as a priority political objective, which then gives way to a series of routinised practices aimed at realising it. In other words, making sense of the persistence of egalitarian and democratic practices implies putting intentionality at the forefront and interpreting observed behaviours as direct manifestations of the egalitarian ethos shared by the group (Boehm, 1993, 1999). In view of this, so-called 'facilitating conditions' also take on a different meaning: the limited size of egalitarian societies is, for instance, best analysed as an intended consequence of - rather than as a facilitating factor for - egalitarian practices (Clastres, 2012: 33). This is particularly true of Scopix, where refusal to grow is commonly articulated among co-operators and knowingly related to democratic requirements.

In fact, Scopix provides a compelling illustration of a co-operative characterised by a reverse dominance hierarchy. At the sheet-metal factory, power is embodied in multiple figures (members of the executive committee, foreman, functional managers etc.) rather than the single figure found in primitive societies. But in both cases, power collectively remains in the 
hands of lay members rather than coalescing in those of their appointed head(s). In both cases, this is to be understood as the outcome of the day-to-day sanctioning activities in which cooperators routinely engage with the ultimate purpose of ensuring the actualisation of egalitarian principles. Within the co-operative context, this model of reverse dominance hierarchy may present some advantages over that of social-movement-like participatory democracy. Indeed, displaying all the features of a classic organisation may allow the cooperative to conform, at least in appearance, with expectations of its dominantly capitalist environment (Meyer and Rowan, 1977). For instance, the existence of a vertical organisational chart may be suggestive of rigour and efficiency. Chiefs, while powerless, may serve as spokespeople in the relationships between the co-operative and its counterparts (e.g. suppliers and customers).

In spite of this, the literature has to date provided very few examples of co-operative settings that would seem to qualify as reverse dominance hierarchies. Closest to this definition is probably the case studied by Warhurst - a thermoplastics factory operated in the form of a kibbutz $^{11}$ - in which he describes a managerial hierarchy that is indeed similarly devoid of authority (Warhurst, 1998). A noticeable difference between this case and that of Scopix is that in the former, the powerlessness of the chiefs seems to stem solely from their own selfrestraint and to exclude any curbing practice from other members. However, there may be two possible reasons for this apparent absence (Boehm, 1993: 234): first, members try not to appoint as their chiefs those whom they perceive as upstarts, and may indeed periodically find the rare gem, i.e. a chief who has no ambition and is not tempted to self-affirm; and second,

\footnotetext{
${ }^{11}$ I here choose to consider the kibbutz form as part of the larger co-operative family since, although ownership takes on a slightly different meaning, most other co-operative principles apply in a similar way (see Warhurst 1996b: 423).
} 
curbing practices may be rather subtle, mostly acting in a pre-emptive fashion, and thus may pass easily under the radar of the ethnographer.

\section{In search of the actual making of co-operation}

In fact, reverse dominance hierarchies may be far more widespread among worker cooperatives than is suggested by the current state of the literature. But finding out implies, as the works of Clastres suggest, further understanding being developed of how co-operatives operate on the ground - that is, at a more micro level than that usually studied. Such studies remain scant in the literature, which has shown an enduring bias in favour of governance issues (Joannidès and Cortese, 2016; Spear et al., 2004). (The recent special issue by Organization on worker co-operatives is illustrative of this long-lasting interest; see Cheney

et al., 2014; Paranque and Willmott, 2014; Storey et al., 2014.) Within this abundant literature, some studies adopt a dominantly normative approach and focus on governance design (e.g. Paranque and Willmott, 2014). Unfortunately, this concern for what co-operation ought to be in theory rather than for what it actually is in practice tends to overlook the forms of decoupling that are likely to separate the actual functioning of co-operative organisations from the devising of their governance mechanisms (Clarke, 1984; Eccles, 1981: 352; HerasSaizarbitoria, 2014). While other studies certainly overcome this limitation, their focus on governance tends to circumscribe their empirical span to a restricted number of processes, situations and spaces - that is, typically, strategic decisions (Hernandez, 2006), and meetings of associates (Ashforth and Reingen, 2014) and of executive committees (Cornforth, 2004; Michaud, 2014). Researchers' fascination for the general assembly, envisaged as the archetypal expression of the democratic phenomenon within co-operative organisations, is illustrative of this overly restrictive conceptualisation of co-operation (e.g. Hernandez, 2006; Viggiani, 1997). Certainly, my intention is not to underplay the importance of a ritual such as 
the general assembly - and of mechanisms of co-operative governance more generally - in the construction of the co-operative reality. Rather, I aim to reiterate that such rituals and mechanisms far-from exhaust all the dimensions of this reality.

The limitations entailed by the governance perspective are well instantiated by the case of Scopix, as interpreted through a Clastrian lens. Within the sheet-metal factory, governance mechanisms seem at first sight to be aimed at conferring some genuine legitimacy and authority on the members of the executive board. However, as I have shown at length, day-today practices directed at those same members have no objective other than to deprive them of such legitimacy and authority. To interpret the case properly, it is therefore of utmost importance to go beyond how the set of formal rules that supposedly govern the co-operative both are devised and work, and to dig into how Scopix actually operates on the ground. The application of the Clastrian perspective to the case of Scopix thus strongly suggests that one of the main challenges in the contemporary study of co-operatives relates to the possibility of investigating co-operation at a level that is anchored in the everyday experience of cooperators. In particular, such study should aim to increase understanding of how co-operative values and principles are embodied in co-operators' more-mundane practices (Sennett, 2013[2012]; Stryjan, 1994), including those that constitute actual power relations (Warhurst, 1998), the concrete organisation of work processes (Hunt, 1992; Kokkinidis, 2015; Warhurst, 1996a, 1998), and their appropriation of management tools (Bryer, 2011, 2014). Finally, researchers should also be ready to accept that such practices may involve feelings and attitudes that do not necessarily carry positive overtones. In the literature, co-operation tends to be naturally associated with the ideas of solidarity, care and giving (Alter, 2009; Birchall, 1997; Bowles and Gintis, 2011; Fairbairn, 1994). However, the case of Scopix, as illuminated by Clastrian insights, demonstrates that the actual making of co-operation may be just as likely to involve sanction, ridicule and debt. 


\section{References}

Alter N (2009) Donner et prendre: La coopération en entreprise. Paris: La Découverte.

Ashforth BE and Reingen PH (2014) Functions of Dysfunction: Managing the Dynamics of an Organizational Duality in a Natural Food Cooperative. Administrative Science Quarterly 59(3): 474-516.

Bakaikoa B, Errasti A and Begiristain A (2004) Governance of the Mondragon Corporacion Cooperativa. Annals of Public and Cooperative Economics 75(1): 61-87.

Bataille-Chedotel F and Huntzinger F (2004) Faces of Governance of Production Cooperatives: An Exploratory Study of Ten French Cooperatives. Annals of Public and Cooperative Economics 75(1): 89-111.

Birchall J (1997) The international co-operative movement. Manchester, UK, New York: Manchester University Press.

Birchall J (2011) People-centred businesses: Co-operatives, mutuals and the idea of membership. Basingstoke [U.K.], New York: Palgrave Macmillan.

Boehm C (1993) Egalitarian Behavior and Reverse Dominance Hierarchy. Current Anthropology 34(3): 227-254.

Boehm C (1999) Hierarchy in the forest: The evolution of egalitarian behavior. Cambridge, Mass.: Harvard University Press.

Bowles S and Gintis H (2011) A cooperative species: Human reciprocity and its evolution. Princeton, N.J., Oxford: Princeton University Press.

Bryer AR (2011) Accounting as learnt social practice: The case of the empresas recuperadas in Argentina. Accounting, Organizations and Society 36(8): 478-493.

Bryer AR (2014) Participation in budgeting: A critical anthropological approach. Accounting, Organizations and Society 39(7): 511-530.

Cathcart A (2013) Directing democracy: Competing interests and contested terrain in the John Lewis Partnership. Journal of Industrial Relations 55(4): 601-620.

Cheney G (1999) Values at work: Employee participation meets market pressure at Mondragón. Ithaca, N.Y.: Cornell University Press.

Cheney G, Santa Cruz I, Peredo AM and Nazareno E (2014) Worker cooperatives as an organizational alternative: Challenges, achievements and promise in business governance and ownership. Organization 21(5): 591-603.

Clarke T (1984) Alternative Modes of Co-operative Production. Economic and Industrial Democracy 5(1): 97-129.

Clastres H (2011) Tableau des terrains de Pierre Clastres. In: Abensour M and Kupiec A (eds) Pierre Clastres. Paris: Sens \& Tonka, pp. 177-178.

Clastres P (1974) La société contre l'État: Recherches d'anthropologie politique. Paris: Éd. de Minuit.

Clastres P (1987) Society against the state: Essays in political anthropology. New York, Cambridge, Mass: Zone Books; Distributed by the MIT Press.

Clastres P (1994) Archeology of violence. New York: Semiotext(e).

Clastres P (2000) Chronicle of the Guayaki Indians. New York: Zone Books.

Clastres P (2012) Entretien avec L'Anti-mythes, 1974. Paris: Sens \& Tonka.

Collinson D (1992) Managing the shopfloor: Subjectivity, masculinity, and workplace culture. Berlin, New York: W. de Gruyter.

Cornforth C (1995) Patterns of Cooperative Management: Beyond the Degeneration Thesis. Economic and Industrial Democracy 16(4): 487-523.

Cornforth C (2004) The Governance of cooperatives and mutual associations: a paradox perspective. Annals of Public and Cooperative Economics 75(1): 11-32. 
Cornforth C, Thomas A, Lewis J and Spear R (1988) Developing successful worker cooperatives. London: Sage Publications.

Diefenbach T and Sillince JAA (2011) Formal and Informal Hierarchy in Different Types of Organization. Organization Studies 32(11): 1515-1537.

Eccles T (1981) Under new management: The story of Britain's largest worker cooperative its successes and failures. London: Pan.

Fairbairn B (1994) The Meaning of Rochdale: The Rochdale Pioneers and the Co-operative Principles. Available at: http://usaskstudies.coop/pdf-files/Rochdale.pdf.

Favret-Saada J (1980) Deadly words: Witchcraft in the bocage. Cambridge [England]: New York; Cambridge University Press.

Flecha R and Ngai P (2014) The challenge for Mondragon: Searching for the cooperative values in times of internationalization. Organization 21(5): 666-682.

Freeman J (2013[1972]) The tyranny of structurelessness. Women's Studies Quarterly 41(3): 231-246.

Geertz C (1973) The interpretation of cultures: Selected essays. New York: Basic Books.

Georgi F (ed.) (2003) Autogestion: La dernière utopie ? Paris: Publications de la Sorbonne.

Graeber D (2009) Direct action: An ethnography. Oakland, Edinburgh: AK Press.

Hardt M and Negri A (2011) The Fight for 'Real Democracy' at the Heart of Occupy Wall Street. Foreign Affairs 11.

Heras-Saizarbitoria I (2014) The ties that bind? Exploring the basic principles of workerowned organizations in practice. Organization 21(5): 645-665.

Hernandez S (2006) Striving for Control: Democracy and Oligarchy at a Mexican Cooperative. Economic and Industrial Democracy 27(1): 105-135.

Hunt GC (1992) Division of Labour, Life Cycle and Democracy in Worker Co-operatives. Economic and Industrial Democracy 13(1): 9-43.

Joannidès V and Cortese C (2016) Cooperatives: governance and accountability systems for a better world? Journal of Accounting \& Organizational Change 12(1).

Joannidès V and Jaumier S (eds) (2014) L'entreprise coopérative. L'organisation de demain ? Paris: Ellipses.

Kasmir S (1996) The myth of Mondragón: Cooperatives, politics, and working-class life in a Basque town. Albany: State University of New York Press.

Kokkinidis G (2015) Spaces of possibilities: workers' self-management in Greece. Organization 22(6): 847-871.

Korczynski M (2011) The Dialectical Sense of Humour: Routine Joking in a Taylorized Factory. Organization Studies 32(10): 1421-1439.

Land C and King D (2014) Organizing otherwise: Translating anarchism in a voluntary sector organization. ephemera 14(4): 923-950.

Leach ER (2004[1964]) Political systems of Highland Burma: A study of Kachin social structure. Oxford: Berg.

Maeckelbergh M (2009) The will of the many: How the alterglobalisation movement is changing the face of democracy. London, New York: Pluto Press.

Maeckelbergh M (2011) The Road to Democracy: The Political Legacy of "1968". International Review of Social History 56(02): 301-332.

Mansbridge JJ (1983) Beyond adversary democracy. Chicago: University of Chicago Press.

Meister A (1984) Participation, associations, development, and change. New Brunswick, N.J: Transaction Books.

Meyer JW and Rowan B (1977) Institutionalized organizations: Formal structure as myth and ceremony. American Journal of Sociology 83(2): 340-363.

Michaud V (2014) Mediating the Paradoxes of Organizational Governance through Numbers. Organization Studies 35(1): 75-101. 
Michels R (1915) Political parties: A sociological study of the oligarchical tendencies of modern democracy. New Brunswick, N.J., U.S.A: Transaction Publishers.

Mouffe C (1996) Democracy, Power and the "Political". In: Benhabib S (ed.) Democracy and difference: Contesting the boundaries of the political. Princeton, N.J.: Princeton University Press, pp. 245-256.

Paranque B and Willmott H (2014) Cooperatives--saviours or gravediggers of capitalism? Critical performativity and the John Lewis Partnership. Organization 21(5): 604-625.

Piven FF and Cloward RA (1979) Poor people's movements: Why they succeed, how they fail. New York: Vintage Books.

Rodrigues SB and Collinson DL (1995) 'Having Fun'?: Humour as Resistance in Brazil. Organization Studies 16(5): 739-768.

Rothschild-Whitt J (1976) Conditions Facilitating Participatory-Democratic Organizations. Sociological Inquiry 46(2): 75-86.

Rothschild-Whitt J (1979) The Collectivist Organization: An Alternative to RationalBureaucratic Models. American Sociological Review 44: 509-527.

Roy DF (1959) "Banana Time": Job Satisfaction and Informal Interaction. Human Organization 18(4): 158-168.

Schneiberg M, King M and Smith T (2008) Social Movements and Organizational Form: Cooperative Alternatives to Corporations in the American Insurance, Dairy, and Grain Industries. American Sociological Review 73(4): 635-667.

Scott JC (2009) The art of not being governed: An anarchist history of upland Southeast Asia. New Haven: Yale University Press.

Seeds For Change (2013) A consensus handbook: Co-operative decision making for activists, co-ops and communities. Lancaster: Seeds For Change.

Sennett R (2013[2012]) Together: The rituals, pleasures and politics of co-operation. London: Penguin.

Simons T and Ingram P (1997) Organization and Ideology: Kibbutzim and Hired Labor, 1951-1965. Administrative Science Quarterly 42(4): 784.

Spear R (2004) Governance in Democratic Member-Based Organisations. Annals of Public and Cooperative Economics 75(1): 33-60.

Spear R, Cornforth C, Chaves R and Schediwy R (2004) Issues in governance of social economy enterprises. Annals of Public and Cooperative Economics 75(1): 3-9.

Storey J, Basterretxea I and Salaman G (2014) Managing and resisting 'degeneration' in employee-owned businesses: A comparative study of two large retailers in Spain and the United Kingdom. Organization 21(5): 626-644.

Stryjan Y (1994) Understanding Cooperatives: The Reproduction Perspective. Annals of Public and Cooperative Economics 61(1): 59-79.

Sutherland N (2013) Book Review: Social movements and activist ethnography. Organization 20(4): 627-635.

Sutherland N, Land C and Bohm S (2014) Anti-leaders(hip) in Social Movement Organizations: The case of autonomous grassroots groups. Organization 21(6): 759-781.

Varman R and Chakrabarti M (2004) Contradictions of Democracy in a Workers' Cooperative. Organization Studies 25(2): 183-208.

Viggiani FA (1997) Democratic Hierarchies in the Workplace: Structural Dilemmas and Organizational Action. Economic and Industrial Democracy 18(2): 231-260.

Warhurst C (1996a) High Society in a Workers' Society: Work, Community and Kibbutz. Sociology 30(1): 1-19.

Warhurst C (1996b) The Management of Production and the Changing Character of the Kibbutz as a Mode of Production. Economic and Industrial Democracy 17(3): 419-445. 
Warhurst C (1998) Recognizing the Possible: The Organization and Control of a Socialist Labor Process. Administrative Science Quarterly 43(2): 470.

Webb S and Webb B (1914) Co-operative production and profit sharing. Special Supplement to the New Statesment 2(45).

Webb T and Cheney G (2014) Worker-owned-and-governed co-operatives and the wider cooperative movement: Challenges and opportunities within and beyond the global economic crisis. In: Parker M, Cheney G, Fournier V and Land C (eds) The Routledge companion to alternative organization. Oxon, New York: Routledge, pp. 64-88.

Zald MN and Ash R (1966) Social Movement Organization: Growth, Decay, and Change. Social Forces 44(3): 327-340. 